\title{
BURGELIJK WETBOEK (Menelusuri Sejarah Hukum Pemberlakuannya di Indonesia)
}

\author{
Erie Hariyanto \\ (D osen jurusan Syari'ah STAIN Pamekasan, Jl. Raya Panglegur Km. \\ 04 Pamekasan, email: erie.mh@gmail.com)
}

\begin{abstract}
:
Burgelijk Wetboek or the book of civil law is historically derived from Dutch. It has been applied on the basis of concordancy principle; in fact, the legislative institution has not published civil laws that being coded and unified yet. It is urgent to apply new laws that exclusively manage law of contract (in particular or general) as a part of civil laws, in order to support the economic activity of nation. Dutch has already revised their own Burgelijk Weboek that has been applied in Indonesia.
\end{abstract}

\section{Keywords:}

Burgelijk W etboek, KUH Perdata, dan Hukum Perdata

\section{Pendahuluan}

Sebagai makhluk sosial setiap manusia selalu mengadakan hubungan dengan manusia lain. Hubungan itu terjadi sejak manusia dilahirkan sampai meninggal dunia. Timbulnya hubungan antar manusia secara kodrati artinya makhluk hidup sebagai manusia itu dikodratkan untuk selalu hidup bersama. Melaksanakan kodrat hidup sebagai proses kehidupan manusia yang terjadi dilakukan sejak lahir sampai meninggal dunia. Bagi setiap manusia dikodratkan memiliki kekayaan diperoleh selama hidupnya yang akan diberikan kepada yang berhak untuk melanjutkan kalau telah meninggal dunia. 
Manusia dikodratkan untuk selalu hidup bersama demi hidupnya, menimbulkan satu jenis hukum yang ketentuannya mengatur tentang kehidupan itu dan dinamakan hukum perdata (privat recht". ${ }^{1}$ Perkataan hukum perdata dalam arti luas meliputi ketentuan-ketentuan dalam hukum perdata materiil yang mengatur kepentingan-kepentingan perseorangan. Hukum perdata materiil ini sering juga disebut "hukum sipil", tetapi karena kata "sipil" lazim digunakan sebagai lawan dari kata "militer", sebaiknya terhadap pemakaian istilah kita gunakan "hukum perdata" saja. Perkataan hukum perdata ada juga yang memberikan dalam arti sempit yaitu lawan dari hukum dagang. Sebenarnya kalau dilihat dari skematik lama yang dimaksud hukum perdata itu terdiri dari hukum sipil dan hukum dagang kurang dapat memberikan suatu kesatuan sistem keperdataan, karena pembagian itu hanya berdasar kepada pembagian undang-undang hukum perdata Belanda sebagai akibat dari sejarah pengkodifikasian sampai ada dua kitab undang-undang hukum dalam satu sistem kaidah hukum perdata.

Kalau dilihat dari kenyataan yang ada, maka sebenarnya hukum perdata di Indonesia terdiri dari: Pertama, hukum perdata adat yaitu ketentuan-ketentuan hukum yang mengatur hubungan antar individu dalam masyarakat adat yang berkaitan dengan kepentingan perseorangan. Masyarakat yang dimaksud di sini adalah kelompok sosial bangsa Indonesia. Ketentuan-ketentuan hukum perdata adat ini pada umumnya tidak tertulis dan berlaku secara turun menurun dalam kehidupan masyarakat adat. Kedua, hukum perdata Eropa yaitu ketentuan-ketentuan hukum yang mengatur hubungan hukum yang menyangkut mengenai kepentingan orangorang Eropa dan orang-orang yang diberlakukan ketentuan itu. Ketiga, bagian hukum perdata yang bersifat nasional yaitu bidangbidang hukum perdata sebagai hasil produk nasional. Bagian hukum perdata nasional yang dibuat itu misalnya hukum perkawinan yang tertuang dalam Undang-undang Nomor 1 Tahun 1974 dan Hukum Agraria yang tertuang dalam Undang-undang Nomor 5 Tahun $1960 .{ }^{2}$

IVollmar, Pengantar Studi H ukum Perdata, (Jakarta: Rajawali, Jakarta, 1989), hlm. 3.

2 Kartini Muljadi, Perikatan pada U mumnya, (Jakarta: RajaGrafindo Persada, 2003), hlm. 
Yang akan dibahas dalam makalah ini adalah hukum Perdata Eropa atau disebut dengan Burgelijk Wetboek (BW) yang kalau diterjemahkan ke dalam Bahasa Indonesia lazim disebut dengan Kitab Undang-undang Hukum Perdata (selanjutnya disebut KUH Perdata)

Dengan diundangkannya KUH Perdata dan Kitab Undangundang Hukum Dagang pada tahun 1847 untuk golongan Eropa di Hindia Belanda, maka tugas-tugas kerja yang bersangkut paut dengan upaya kodifikasi yang diprakarsai dan ditata oleh eksponeneksponen bewuste rechtspolitiek untuk mengukuhkan supremasi hukum di Hindia Belanda. ${ }^{3}$ Alasan diterapkannya KUH Perdata di Hindia Belanda antara lain di sebutkan oleh Cowan yaitu: Pertama, hukum adat yang tak tertulis akan menimbulkan ketidakpastian hokum, dan apabila orang cuman bersandar pada hukum adat maka sulit untuk memperkirakan apa yang boleh dijangka akan diputus oleh hakim. Kedua, penerapan berbagai hukum untuk berbagai ragam golongan-golongan penduduk akan melahirkan situasi yang membingungkan dan kritis.

Sudah dijelaskan bahwa yang dimaksud dengan hukum perdata adalah rangkaian peraturan yang mengatur hubungan antara warga negara perseorangan dengan warga negara perseorangan yang lain. Sedangkan hukum perdata tertulis yang dimaksud dalam makalah ini adalah hukum perdata yang diatur di dalam KUH Perdata (Burgelijk W etboek).

Sejak awal kemerdekaan sudah ada usaha untuk mengantikan seluruh hukum kolonial dengan sistem hukum nasional, namun kegagalan karena adanya perbedaan pandangan dalam melihat pembangunan hukum, yaitu apakah harus mengunakan hukum nasional dan membuang sama sekali hukum sisa peninggalan kolonial, di lain pihak masih banyak yang menghendaki berlaku bersama-sama, selain itu ada pandangan untuk mengunakan hukum adat sebagai hukum nasional.

3 Soetandjo Wingjosoebroto, Dari Hukum Kolonial ke Hukum Nasional, Jakarta: Rajawali Press, 1995), hlm.56 
Kita tahu bahwa walaupun KUH Perdata di atas pada awalnya (sebelum negara Indonesia merdeka) dinyatakan berlaku bagi orang Belanda, namun kenyataannya sampai sekarang masyarakat Indonesia tetap menggunakan KUH Perdata sebagai salah satu hukum yang akan menentukan dalam pergaulan masyarakat.4 Apalagi sampai saat ini lembaga legislatif kita belum mampu membuat hukum perdata yang sudah terkodifikasi dan berlaku secara unifikasi. 5 Tetapi untuk Indonesia mutlak diperlukan undang-undang baru yang khusus mengatur hukum kontrak, baik yang khusus, maupun yang merupakan bagian dari undang-undang hukum perdata6.

Berkenaan dengan hal itu, masalah yang disajikan dalam tulisan ini adalah: (1) Bagaimanakah sejarah berlakunya dan sistematika KUH Perdata (BW) di Indonesia?; (2) Sejauh manakah perubahan-perubahan terhadap KUH Perdata (BW) oleh perundangundangan Republik Indonesia dan di negara Belanda.

\section{Sejarah Hukum Burgelijk W etboek}

Hukum perdata semula berasal dari bangsa Romawi yaitu lebih kurang 50 SM pada masa pemerintahan Yulius Caesar berkuasa di Eropah Barat yang sejak waktu itu hukum Romawi diberlakukan di Perancis walaupun bercampur dengan hukum asli yang sudah ada sebelum orang Romawi menguasai Galis (Perancis). Keadaan seperti ini terus berlangsung sampai pada masa pemerintahan Louis XV yaitu dengan diawalinya usaha kearah adanya kesatuan hukum yang kemudian menghasilkan suatu kodifikasi yang diberi nama "Code Civil Des Francois"7 pada 21 Maret 1804 yang kemudian pada 1807 diundangkan kembali menjadi "Code $\mathrm{N}$ apoleon".

Kodifikasi ini sangat berbau Romawi tetapi para penyusunnya banyak juga memasukkan kedalamnya unsur-unsur hukum asli yaitu

4Subekti, Pokok-pokok H ukum Perdata, cet. XXVII, (Jakarta: Intermasa,1995), hIm. 10. 5lbid.

6A hmadi Miru, Hukum Kontrak dan Perancangan Kontrak, (Jakarta: RajaGrafindo Persada, 2007), hlm. 4

7Wirjono Projodikoro, A zas-azas H ukum Perdata, Cet. IX, (Bandung: Sumur Bandung, 1983), hlm. 9. 
hukum adat Perancis Kuno (hukum Jerman) yang telah berlaku di Eropah Barat sebelum orang-orang Romawi menguasai Perancis. Sebagai campuran ketiga di dalam isi Code Civil itu adalah hukum gereja atau hukum Katolik yang didukung oleh gereja Roma Katolik ketika itu.

Pada 1811, Belanda di jajah oleh Perancis dan seluruh Code Civil yang memuat ketiga unsur yaitu hukum Romawi, Hukum German dan hukum Gereja diberlakukan di negeri Belanda dan oleh karena Indonesia pada waktu itu merupakan jajahan Belanda maka hukum perdata Belanda yang sebagian besar berdasarkan pada Code Civil itu diberlakukan pula untuk Indonesia sejak 1 Januari 1848 dengan Staatsblad tahun 1847 No. 23. Namun demikian, hukum perdata di Indonesia agak berlainan dengan hukum perdata yang berlaku di negeri Belanda apalagi jika dibandingkan dengan Code Civil Perancis, hanya asas-asasnya banyak diambil dari Code Civil.

Berlakunya hukum perdata Belanda tersebut di Indonesia bertalian erat dengan politik hukum pemerintah Hindia Belanda yang membagi penduduk Hindia Belanda menjadi 3 golongan yaitu: (1) Golongan Eropa yaitu semua orang Belanda, orang yang berasal dari Eropa, orang Jepang, orang yang hukum keluarganya berdasarkan azas-azas yang sama dengan hukum Belanda beserta anak keturunan mereka; (2) Golongan Timur Asing Tionghoa dan Timur Asing bukan Tionghoa misalnya orang A rab, India dan Pakistan; (3) Mereka yang telah meleburkan diri dan menyesuaikan hidupnya dengan golongan Bumi Putera.

Penggolongan tersebut diatur dalam pasal 163 IS (Indische Staatsregeling) yang sampai sekarang masih tetap berlaku berdasarkan ketentuan pasal 2 A turan Peralihan Undang-undang Dasar 1945.8

Mengenai hukum apa yang berlaku bagi masing-masing golongan diatur dalam pasal 131 IS yang menentukan, bahwa: Pertama, bagi golongan Eropa berlaku hukum perdata dan hukum Dagang yang berlaku di Negara Belanda atas dasar azas konkordansi. Kedua, bagi golongan Timur Asing Tiongha berlaku hukum perdata yang diatur dalam BW dan Hukum Dagang yang diatur dalam KUHD (WvK ) dengan beberapa pengecuaian dan

8Subekti, Pokok-pokok, hlm 34 
penambahan sebagaimana diatur dalam stablad tahun 1917 Nomor 129 jo Stb. Tahun 1925 Nomor 557. Pengecualian dan penambahan meliputi : (a) Upacara Perkawinan; (b) Pencegahan Perkawinan; (c) Kantor Pencatatan Sipil (Burgerlijk Stand); (d) Pengangkatan anak (adopsi); (e) Peraturan tentang kongsi. Bagi golongan timur asing bukan Tinghoa berlaku hukum perdata Eropa sepanjang mengenai hukum harta kekayaan sedang mengenai hukum kekeluargaan dan hukum waris tunduk pada hukum asli mereka sendiri. Hal ini diatur dalam Staatblad tahun 1924 Nomor 556 yang mulai berlaku sejak 1 Maret 1925. Ketiga, dari golongan bumi putra berdasarkan ketentuan pasal 131 ayat 6 IS berlaku hukum perdata adat yaitu keseluruhan peraturan hukum yang tidak tertulis tetapi hidup dalam tindakan - tindakan rakyat sehari -hari. Dalam pada itu hukum perdata adat masih belum seragam sesuai dengan banyaknya lingkungan hukum adat (adat rech skiringen) di Indonesia.

Dalam pada itu, berdasarkan ketentuan pasal 131 ayat 2 IS peraturan-peraturan untuk orang Eropa dapat diberlakukan untuk golongan Indonesia asli/ Timur Asing secara utuh maupun dengan perubahan-perubahan, untuk membuat peraturan baru yang berlaku untuk semua golongan bersama- sama dan diadakan penyimpanganpenyimpangan umum/ masyarakat memerlukan. Pertama, beberapa ketentuan BW dan WvK yang dinyatakan berlaku bagi golongan bumi putra, yaitu: (a) Pasal-pasal tentang perjanjian kerja atau perburuhan (Ps. 1601- 1603 lama BW ); (b) Pasal - pasal tentang permainan dan perjudian pasal 1788- 1791 BW); (c) Pasal-pasal mengenai hukum laut (buku II titel IV KUHD Stb. 1933 Nomor 49). Kedua, beberapa peraturan yang berlaku bagi semua golongan (Gemeen schappelijk recht), yaitu: (a) Undang - undang Hak Pengarang (A uterswet St. 1912- 308); (b)Peraturan umum tentang koperasi (Stb. tahun 1933 Nomor 108); (c) Ordonansi pemberantasan riba (Stb. 938 No. 524); (d) Ordoonansi pengangkutan udara (Stb. 1939 No. 98). Ketiga, beberapa peraturan yang secara khusus di buat untuk orang Indonesia, yaitu: (a) Ordonansi perhimpuan Indonesia (Stb. 1939 No. 570 ); (b) Ordonansi maskapai andil Indonesia (Stb. 1939 - Nomor 569) dan (c) Ordonansi perkawinan orang Indonesia Kristen (Stb. 1933 Nomor 74 jo S. 1933 N omor 73). 
Burgelijk Wetboek

\section{Sistimatika Burgelijk Wetboek}

Sistematika Burgelijk Wetboek terdiri atas: Pertama, Perihal Orang ( $V$ an Personen), yang mengatur tentang hukum badan pribadi dan hukum keluarga. Kedua Perihal Benda (Van Zaken), yang mengatur tentang benda termasuk di dalamnya hukum waris. Ketiga, Perihal Perikatan (V an V erbintenissen), yang mengatur tentang hukum kekayaan yang mengenai hak-hak dan kewajiban-kewajiban yang berlaku terhadap orang-orang atau pihak-pihak tertentu. Keempat, Perihal pembuktian dan Lewat Waktu (Van Bewijaeu Veryaring). Sistimatika tersebut di atas sangat dipengaruhi oleh sistem institutiones Justiniasnse.

Jika kita bandingkan kedua sistematika tersebut di atas, terdapat perbedaan atau ketidaktepatan-ketidaktepatan sebagai berikut, yaitu: Pertama, BW mengatur hukum keluarga sebagai bagian dari buku I (hukum badan pribadi) dengan alasan bahwa di dalam hukum keluarga terdapat hubungan-hubungan yang mempengaruhi kecakapan bertindak dari subyek hak atau person. Kedua, BW mengatur hukum waris sebagai bagian dari buku II (buku benda) dengan alasan karena pembentuk Undang-undang memandang hak waris itu sebagai suatu hak kebendaan atas harta kekayaan dari orang yang meninggal dunia. Pewarisan dianggap sebagai salah satu cara untuk memperoleh eigendom, sedangkan eigendom adalah merupakan suatu hak kebendaan. Ketiga, dalam sistimatik ilmu pengetahuan hukum benda dan hukum perikatan tidak diatur tersendiri sebab hukum harta kekayaan sebagai aturan yang mengatur hubungan hukum yang dapat dinilai dengan uang dapat ditimbulkan karena hak- hak kebendaan yang diatur dalam buku II BW maupun yang ditimbulkan karena perikatan seperti diatur dalam buku III BW. K eempat, pengaturan alat bukti dan lewat waktu dalam buku IV BW di pandang kurang tepat karena merupakan soal hukum acara, sedang BW mengatur tentang hukum perdata pokok.

\section{Perubahan-perubahan terhadap Berlakunya KUH Perdata di Indonesia}


Dalam mempelajari dan menerapkan ketentuan-ketentuan hukum perdata perlu diperhatikan adanya ketentuan peraturan perundang-undangan Indonesia yang mempengaruhi dan mengubah isi serta berlakunya KUH Perdata di Indonesia. Dengan demikian dapat diketahui pasal-pasal mana yang dianggap tidak berlaku atau dicabut sehubungan dengan adanya peraturan-peraturan baru tersebut.

Dengan ditetapkannya Undang-undang Nomor 5 tahun 1960 tanggal 24 September 1960, Stb. tahun 1960 Nomor 104 tentang Undang-Undang Pokok Agraria (UUPA) mencabut semua ketentuanketentuan mengenai hak-hak kebendaan yang bertalian dengan tanah dari buku II BW (KUHP) kecuali mengenai hipotek. Artinya semua ketentuan-ketentuan yang mengenai hak kebendaan yang bertalian dengan tanah mendapat pengaturannya di dalam hukum Agraria dan tidak menjadi obyek hukum perdata lagi.

Dengan adanya Surat Edaran Mahkamah Agung tanggal 5 September 1963 N omor 3 Tahun 1963, beberapa pasal atau ketentuan dipandang tidak berlaku lagi, yaitu: (a) Pasal 108 -110 BW tentang ketidakwenangan bertindak seorang istri; (b) Pasal 284 ayat 3 BW tentang pengakuan anak luar kawin yang lahir dari seorang wanita Indonesia; (c) Pasal 1682 BW tentang keharusan dilakukannya hibah dengan akte notaris; (d) Pasal 1579 BW tentang penghentian sewa menyewa dengan alasan akan memakai sendiri barang itu; (e) Pasal 1238 BW tentang pengajuan gugat pelaksanaan suatu perjanjian. (f) Pasal 1460 BW tentang resiko dalam perjanjian jual beli barang; dan (g) Pasal 1603 ayat 1 dan 2 BW diskriminasi orang Eropa dan bukan Eropa dalam perjanjian perburuhan.

Dengan berlakunya Undang-undang Nomor 1 tahun 1974 tanggal 2 Januari 1974 Jo. Peraturan Pemerintah Nomor 9 tahun 1975 tanggal 1 April 1975 tentang Undang-Undang Pokok Perkawinan yang mengganggap tidak berlaku lagi semua peraturan-peraturan yang mengatur perkawinan sepanjang telah diatur dalam Undangundang tersebut yaitu: (1) Ketentuan-ketentuan perkawinan dalam KUH Perdata (BW); (2) Ordonansi Perkawinan Indonesia Kristen (Buwelijksor donantio chesten Indonesiers) seperti tercantum dalam Staatsblad tahun 1933 nomor 74; (3) Peraturan Perkawinan Campuran (Regeling Opde Gemengde Huwelijkken) seperti tercantum di dalam 
staatsblad tahun 1898 nomor 158; (4) Peraturan-peraturan lain yang mengatur tentang perkawinan.

Undang-undang no. 42 tahun 1999 tentang jaminan fidusia telah mengantikan pengaturan tentang jaminan fidusia telah digunakan di Indonesia sejak zaman penjajahan Belanda sebagai suatu bentuk jaminan yang lahir dari yurisprudensi. Bentuk jaminan ini digunakan secara luas dalam transaksi pinjam-meminjam karena proses pembebanannya dianggap sederhana, mudah, dan cepat, tetapi tidak menjamin adanya kepastian hukum. Lembaga Jaminan Fidusia memungkinkan kepada para pemberi fidusia untuk menguasai benda yang dijaminkan, untuk melakukan kegiatan usaha yang dibiayai dari pinjaman dengan menggunakan jaminan fidusia. Pada awalnya, Benda yang menjadi objek fidusia terbatas pada kekayaan benda bergerak yang berwujud dalam bentuk peralatan. A kan tetapi dalam perkembangan selanjutnya, benda yang menjadi objek fidusia termasuk juga kekayaan benda bergerak yang tak berwujud, maupun benda tak bergerak.

Dalam perkembangannya selama ini, kegiatan pinjammeminjam dengan menggunakan hak tanggungan atau hak jaminan telah diatur dalam Undang-undang N omor 4 Tahun 1996 tentang Hak Tanggungan yang merupakan pelaksanaan dari Pasal 51 Undangundang Nomor 5 Tahun 1960 tentang Undang-undang Pokok Agraria, dan sekaligus sebagai pengganti dari lembaga hipotek atas tanah dan credietverband. Di samping itu, hak jaminan lainnya yang banyak digunakan pada dewasa ini adalah gadai, hipotek selain tanah, dan jaminan fidusia. Undang-undang yang berkaitan dengan jaminan fidusia adalah Pasal 15 Undang-undang Nomor 4Tahun 1992 tentang Perumahan dan Permukiman, yang menentukan bahwa rumah-rumah yang dibangun di atas tanah yang dimiliki oleh pihak lain dapat dibebani dengan jaminan fidusia. Selain itu, Undangundang Nomor 16 Tahun 1985 tentang Rumah Susun mengatur mengenai hak milik atas satuan rumah susun yang dapat dijadikan jaminan utang dengan dibebani fidusia, jika tanahnya tanah hak pakai atas tanah negara.

Burgelijk W eetbook Baru Belanda (BWBB) telah berhasil diubah, dirombak, singkatnya dimodernisasi, sehingga dapat mengikuti perkembangan jaman, khususnya menunjang berbagai kegiatan kegiatan ekonomi dalam arti luas. Upaya perubahan dan modernisasi 
diawali dalam tahu 1947 dan baru berhasil akhir tahun 1992 dengan pengundangan BWBB yang dinyatakan berlaku mulai 1 januari 1992. buku 1 (orang dan keluarga) dan Buku 2 (Badan Hukum) sudah dinyatakan berlaku, yaitu berturut -turut tentang jual beli dan tukar menukar (koop en huur), pemberian kuasa (lestgeving), Penitipan (bewaargeving), dan penanggungan (borgtocht)9. Buku 7A akan memuat kontrak-kontrak khusus yang terdapat di dalam BW lama Belanda di luar BAB 1,7,9 dan 14 buku 7. Buku 8 tentang alat-alat angkut dan pengakutan (verkeermiddlen en vervoer) berisi Undang-undang pengangkutan yang dinyatakan berlaku sejak 1 A pril 1992

Dengan demikian, ternyata masih ada yang belum tuntas dalam kegiatan modernisasi tersebut, walaupun mereka mempunyai banyak tenaga ahli dengan dukungan dana serta fasilitas yang cukup, masih diperlukan waktu hampir limapuluh tahun. Bagaimana dengan Indonesia kelihatannya modernisasi hanya dapat dilakukan dengan membuat aturan hukum perdata secara parsial dalam undang yang mengatur secara khusus seperti Undang-undang Pokok Agraria, Undang-undang Perkawinan, Lembaga Hukum Jaminan fidusia dan dalam bidang hukum perdata yang lain.

\section{Penutup}

Burgelijk W etboek atau dalam bahasa Indonesia lebih dikenal dengan KUH Perdata menurut sejarah adalah berasal dari Belanda yang diberlakukan di Indonesia berdasarkan azas konkordansi. Walaupun pada awalnya diberlakukan bagi orang keturunan Belanda (termasuk di dalamnya orang Eropa dan Jepang), namun setelah Indonesia merdeka ternyata masyarakat Indonesia tetap mempergunakannya dalam memecahkan masalah-masalah perdata.

KUH Perdata (BW) yang dibuat pada awal abad 18 dan diberlakukan di Indonesia pada abad 19 ternyata ada beberapa yang sudah ketinggalan jaman atau dengan kata lain sudah tidak sesuai lagi dengan kebutuhan dalam masyarakat. Dengan demikian diharapkan badan legislatif berupaya semaksimal mungkin

\footnotetext{
9 Redaksi, Jurnal hukum Ekonomi, N ew Burgelijk W etboek Belanda Edisi III (Pebruari 1996), hlm. 12
} 
menciptakan hukum perdata nasional atau kalau memang belum mampu mencipta undang-undang pengganti BW.

Burgelijk Wetboek (KUH Perdata) yang berlaku di Indonesia berdasarkan asas konkordansi dalam kenyataannya terdapat beberapa hal yang tidak sesuai nilai-nilai ataupun dengan perkembangan masyarakat. Karenanya hakim nantinya dalam menafsirkan pasal-pasal yang terdapat dalam BW tersebut harus mengedepankan keadilan. Selanjutnya dengan harapan semoga badan legislatif mampu membuat hukum perdata nasional yang mampu diterima oleh semua kalangan masyarakat, dimana belanda sendiri sudah melakukan modernisasi terhadap Burgelijk Wetboek lamanya.

Namun dalam pembangunan Hukum yang akan datang diharapkan tidak melupakan sejarah, artinya asas-asas yang sudah sesuai tidak perlu dibuang, adanya Undang-undang tentang Fidusia, Undang-undang Perkawinan yang baru, atau undang-undang tentang Pengelolaan Sumber Daya Alam dan banyak lainnya yang mengatur masalah perdata maka peran dari KUH Perdata (BW) makin bisa dikurangi yang pada akhirnya akan hanya menjadi naskah akademik bukan lagi sebagai sebuah Undang-undang yang harus ditaati oleh rakyat Indonesia

\section{D aftar Pustaka:}

Masjchun, Soedewi Sri. Hukum Badan Pribadi. Yogyakarta: Yayasan Penerbit Gadjah Mada, 1984

Miru, Ahmadi. Hukum Kontrak dan Perancangan Kontrak. Jakarta: RajaGrafindo Persada, 2007

Muljadi, Kartini. Perikatan Pada Umumnya, Jakarta: RajaGrafindo Persada, 2003

Prawirohamidjojo, Soetojo. Hukum Orang dan Keluarga. Bandung: Alumni, 1982 
Erie Hariyanto

Prodjodikuro, Wirjono. Azas-azas Hukum Perdata. Jakarta: PT Intermasa, 1974

Redaktur, Jurnal Hukum Ekonomi, Edisi III (Pebruari, 1996)

Subekti. Pokok-pokok H ukum Perdata. Jakarta: PT Intermasa, 1980

Vollmar. Pengantar Studi H ukum Perdata. Jakarta: Rajawali, 1989

Wignjosoebroto, Soetandjo. Dari Hukum Kolonial ke Hukum Nasional. Jakarta: Rajawali Pers, 1995 